\title{
ОСОБЛИВОСТІ СТАНОВЛЕННЯ ПРОФЕСІЙНОЇ ІДЕНТИЧНОСТІ В МАЙБУТНІХ ПСИХОЛОГІВ У ПРОЦЕСІ НАВЧАННЯ
}

\author{
Олексій Ляшенко \\ кандидат психологічних наук, доцент \\ кафедри теоретичної та консультативної психології \\ Національний педагогічний університет імені М.П. Драгоманова \\ 01601, Україна, м. Київ, вул. Пирогова, 9 \\ o.a.lyashenko@npu.edu.ua, https://orcid.org/0000-0002-2942-8284
}

\begin{abstract}
Анотація
Стаття присвячена проблемі становлення професійної ідентичності в майбутніх психологів. Мета полягала в емпіричному виявленні відмінностей розвитку показників професійної ідентичності на різних етапах навчання майбутніх психологів у бакалавраті. Теоретично досліджені основні погляди вчених на процес професійного становлення психологів (консультантів, психотерапевтів). Розглянуто особливості професійної ідентичності психологів у порівнянні з іншими професіями. Акцент ставиться на важливості приділення уваги становленню професійної ідентичності майбутніх психологів вже на етапі їхнього навчання у ЗВО. Розглянуто ключові періодизації розвитку професійної ідентичності спеціалістів допомагаючих професій, окремо виділено студентський період, в межах якого в майбутніх психологів має сформуватися чітке бачення себе як спеціаліста та окреслитися бачення власного професійного шляху. Емпірично досліджено особливості вияву професійної ідентичності $з$ першого по четвертий курс навчання на бакалавраті. Детально розглянуто особливості емоційного ставлення студентів до власної професії та активної позиції щодо оволодіння професією психолога. Основна увага акцентується на зміні емоційного ставлення до спеціальності та професії від позитивного до негативного протягом навчання на бакалавраті. Серед основних причин такого знецінення виділяються дезадаптованість студентів під час початку навчання, напружений психологічний клімат в студентській групі, мала кількість навчальних годин, що приділяється особистісному розвитку студентів та розвитку готовності до взаємодії із клієнтами. В результаті цього студенти старших курсів виявляються психологічного не готовими до професійної діяльності, а тому обирають інші шляхи самореалізації. У висновках дається бачення того, що негативне ставлення та неприйняття себе в ролі психолога часто пов'язане із низькою адаптацією студентів до навчального процесу, відсутністю позитивного психологічного клімату всередині групи, недостатньою кількістю навчальних годин, спрямованих на особистісний розвиток студентів. Ключові слова: професійна ідентичність, професійне становлення психолога, психологконсультант, ціннісне ставлення до професії, активна позиція, адаптація до навчання.
\end{abstract}

\section{Вступ}

Сучасне суспільство розвивається все більшими темпами, а разом з ним розвиваються й технології, засоби спілкування, навчання. Цей темп, з однієї сторони, дозволяє розвиватися, більше продукувати та заробляти, а, з іншого - все частіше в людей з'являються психологічні проблеми, пов'язані з цими явищами. Населення частіше звертається до психологів, психотерапевтів, консультантів за допомогою. Тому сьогодні особливо актуальним є питання 
підготовки професійних психологів, консультантів, психотерапевтів та ін.. Ця професія відноситься до однієї з найбільш емоційно виснаджуючих, а спеціалісти часто емоційно та професійно вигорають.

Такий стан пов'язаний з декількома основними проблемами. Перша - це те, що психологи мають вислуховувати та емпатійно розуміти труднощі своїх клієнтів та співпереживати їм. Психологу потрібно одночасно бути розуміючим та підтримуючим, дозволяти клієнту побути зі своєю проблемою, прийняти свої слабкості тощо, а, з іншої сторони - мотивуючим та таким, який допомагає знаходити виходи зі складних ситуацій. Друга важлива проблема пов'язана із тим, що самі психологи також зустрічаються 3 труднощами в особистому житті та професійній діяльності. Особливо це стосується психологів, які знаходяться на перших етапах свого професійного становлення. Часто довге переживання таких труднощів пов'язане 3 низьким розвитком власної професійної ідентичності як психолога.

Загалом проблема ідентичності особистості досить актуальна сьогодні. У науковій психологічній літературі можна побачити погляди вчених на «гендерну», «сексуальну», «расову», «соціальну», «особистісну» ідентичності та ін.. I, якщо більшість запропонованих феноменів можна досліджувати у всього населення загалом, то особливості розвитку й вияву професійної ідентичності можуть суттєво відрізнятися в залежності від специфіки самої професії. Так, C.R. Auxier; Frances R. Hughes \& William B. Kline (2003) вказували на те, що на відміну від представників більшості професій, психологи мають сформувати не тільки ставлення до себе як до професіонала, але й розробити власне «терапевтичне Я», що має поєднувати його професійну та особистісну сторону особистості. Таке поєднання вимагає постійної роботи над собою в процесі підготовки, систематичного «опрацювання» власних психологічних життєвих труднощів із спеціалістами та переосмислення попередньо сформованих поглядів на різноманітні сторони свого життя.

Важливо розуміти, що процес формування професійної ідентичності психолога (консультанта, психотерапевта) безперервний, а тому його варто розглядати в розрізі всього періоду підготовки та професійної діяльності фахівця.

В англомовній психологічній літературі, яка стосується проблеми професійного розвитку психологів, одними з найбільш поширених є праці M.H. Rønnestad \& T.M. Skovholt (1992, 2003), в межах яких вчені виділяли 8 стадій розвитку консультанта/психотерапевта (1992): донавчальна стадія «Звичаного помічника» (Conventional helper); три студентські стадії: «Перехід до професійного навчання» (Transition to Professional Training), «Імітація» (Imitation) та «Умовна автономія» (Conditional Autonomy); чотири післянавчальні стадії: «Дослідження» (Exploration), «Інтеграція» (Integration) «Індивідуація» (Individuation), «Цілісність» (Integrity). У подальшому досліджені ці стадії були об'єднані та перейменовані у 6 фаз (2003): «Світського помічника» (Lay Helper), «Студента-початківця» (Beginning Student), «Прогресуючого студента» (Advanced Student), «Новачка-професіонала» (Novice Professional), «Досвідченого професіонала» (Experienced Professional) та «Старшого професіонала» (Senior Professional) (2003).

Студентський період представлений двома фазами - «Студента початківця» та «Прогресуючого студента». Порівнюючи зі специфікою навчання на спеціальності «Психологія» в Україні можна умовно співставити ці фази з навчанням на бакалавраті та в магістратурі. Це пов'язано із тим, що «студенти-початківці» вже активно залучаються до консультативної практики в університеті, а також до самостійної професійної діяльності. Обов'язковим для таких студентів є супервізорський супровід, а також демонстрація моделі 
консультативної діяльності, яку вони частіше за все й намагаються відтворити. Водночас, студенти, які навчаються в магістратурі, часто вже працевлаштовані за спеціальністю та мають можливість надавати консультативну та психотерапевтичну (під наглядом супервізіра) допомогу клієнтам. Такі студенти могли пройти додаткове навчання в межах певного методу (підходу) та, побачивши декілька різних моделей надання консультативної допомоги, розпочинають виробляти власну індивідуальну модель надання психологічної допомоги. Варто зауважити, що на цьому етапі студентам так само обов'язково необхідна підтримка супервізорів, викладачів та професійного середовища (інтервізійні групи).

Варто відзначити, що саме студентські стадії становлення професійної ідентичності мають визначний вплив на усвідомлене розуміння професії, себе та свого місця в ній. У цей період майбутні психологи змінюють свої загальні уявлення про обрану професію та визначають для себе власне іiі розуміння, усвідомлюють свої сильні та слабкі якості, які сприяють професійному розвитку. Також закладаються базові етичні принципи роботи й позиціювання себе в соціумі як професіонала. Тому, важливо зрозуміти як саме відбувається процес розвитку професійної ідентичності майбутніх психологів у межах цього періоду.

Розглядаючи розвиток професійної ідентичності як процесу успішної інтеграції особистісних якостей та професійної підготовки в контексті професійної спільноти, N. Thacker та J. Diambra (2019) приділяли особливу увагу взаємодії студентів, що навчаються 3 викладачами, які також навчаються, але на докторських програмах. Вчені вказують на той позитивний взаємозв'язок, який має допомагати обом групам. Студенти отримують можливість супервізії, підтвердження власних старань та підкріплення впевненості для продовження навчання. Викладачі-докторанти, в свою чергу, мають можливість отримувати від студентів беспосердні знання про їхній професійній розвиток та вдосконалювати свої навички викладання.

У своєму дослідженні В.В. Левченко (2019) наголошує на ролі мотиваційної складової та зрілості інтересів майбутніх психологів у формуванні їхньої професійної ідентичності. Вчена виділяє три групи чинників (психологічні, особистісні та соціальні), від яких залежить успішність розвитку досліджуваного феномена. Серед останніх варто виділи супровід процесу становлення професійної ідентичності та наявність соціально-психологічної підтримки студентів у тих ситуаціях, які є для них новими.

У попередньому нашому досліджені (Ляшенко, 2015) ми, вивчаючи становлення психологічної позиції рівності майбутніх викладачів психології, змогли дослідити особливості професійної ідентичності майбутніх психологів та зрозуміти можливі причини відмінності в результатах двох груп студентів. До вибірки були залучені студенти IV курсу бакалаврату та I курсу магістратури. За результатами психодіагностичного обстеження було встановлено, що високий рівень ставлення до власної професії зустрічається частіше в магістрантів $(15,1 \%$ та $25,3 \%$ ), що проявляється в розумінні необхідності, актуальності та суспільного визнання професії психолога, а також у чіткому бажані продовжувати працювати та розвиватися в психологічній спеціальності. Високий рівень активної позиції до оволодіння своєю професією також суттєво переважає в магістрантів (21,9\% та 42,3\%), що може бути пов'язане із чітким розумінням важливості отримуваних знань для подальшої професійної діяльності, готовності до додаткового навчання (семінари, конференції, навчання обраному методу надання психологічної допомоги). Такі результати змусили замислитися про особливості розвитку професійної ідентичності майбутніх психологів у межах чотирирічної бакалаврської підготовки. 
Мета дослідження полягала у емпіричному вивченні відмінностей розвитку показників професійної ідентичності на різних етапах навчання майбутніх психологів у бакалавраті. Завдання дослідження: 1) теоретично дослідити основні погляди вчених на процес професійного становлення психологів (консультантів, психотерапевтів); 2) емпірично виявити відмінності розвитку показників професійної ідентичності на різних етапах навчання майбутніх психологів у бакалавраті.

\section{Методи дослідження}

Для виявлення особливостей розвитку професійної ідентичності в студентів-майбутніх психологів протягом навчання в університеті на освітньому рівні «бакалавр» нами було використано порівняльний метод (поперечного зрізу). Для досягнення даної мети було залучено 110 студентів денної форми навчання спеціальності «Психологія» факультету психології НПУ імені М.П. Драгоманова. Серед них на першому курсі 26, на другому - 29, на третьому - 28 та на четвертому курсі 27 досліджуваних. Більшість студентів поступили в університет одразу після школи у віці 16-18 років і на момент дослідження всім було від 17 до 22 років, у залежності від курсу. Усі досліджувані обирали професію, спостерігаючи за нею зі сторони та не маючи власного консультативного (психотерапевтичного) досвіду, окрім досвіду взаємодії зі шкільним психологом.

Емпіричне дослідження особливостей розвитку професійної ідентичності було проведено за допомогою «Опитувальника професійної ідентичності студентів-майбутніх психологів» (Родигіна, 2007). Методика складається з 20 тверджень, погодження/заперечення з якими потрібно оцінити за п'ятибальною шкалою. Специфіка цієї методики полягає в тому, що вона дозволяє виявити особливості розвитку двох основних компонентів (шкал) «Емоційне ставлення до майбутньої професії» та «Усвідомлена (активна) позиція до оволодіння майбутньою професією». Ця методика розроблена та адаптована спеціально для студентів психологічних спеціальностей та включає питання, що стосуються саме діяльності майбутнього психолога.

В подальшому були проведені бесіди зі студентами для розуміння пояснення отриманих емпіричних результатів. Результати діагностики за методикою «Опитувальник професійної ідентичності студентів-майбутніх психологів» оброблено та представлено у вигляді таблиць (Таб.1 та Таб.2). Всі процедури відбувалися протягом березня-квітня 2019 року, щоб зменшити вплив екзаменаційно-залікових сесій на емоційний настрій та зосередитися більше на баченні обраної професії, а не на навчальних успіхах/невдачах.

\section{Результати та дискусії}

Табличя 1

\section{Кількісні показники рівнів прояву позитивного емоційного ставлення до власної майбутньої професії в студентів I-V курсів ( у \%)}

\begin{tabular}{|l|c|c|c|c|c|c|}
\hline & \multicolumn{2}{|c|}{ Високий } & \multicolumn{2}{c|}{ Середній } & \multicolumn{2}{c|}{ Низький } \\
\hline & $\mathrm{n}$ & $\%$ & $\mathrm{n}$ & $\%$ & $\mathrm{n}$ & $\%$ \\
\hline I курс $(\mathrm{n}=26)$ & 9 & 34,62 & 10 & 38,46 & 7 & 26,92 \\
\hline II курс $(\mathrm{n}=29)$ & 4 & 13,80 & 18 & 62,07 & 7 & 24,13 \\
\hline III курс $(\mathrm{n}=28)$ & 5 & 17,86 & 15 & 53,57 & 8 & 28,57 \\
\hline IV курс $(\mathrm{n}=27)$ & 6 & 22,22 & 10 & 37,04 & 11 & 40,74 \\
\hline Загалом $(\mathrm{n}=110)$ & 24 & 21,82 & 53 & 48,18 & 33 & 30.00 \\
\hline
\end{tabular}


Як видно з таблиці 1, серед студентів I-IV курсів високий рівень емоційно-ціннісного (позитивне ціннісне) ставлення до обраної майбутньої професії зустрічається в 21,82\% респондентів. Такі досліджувані бачать професію психолога в позитивному контексті, визначають іï суспільно-корисною. Під час опису обраної професії більшість таких респондентів готові оцінити та обгрунтувати необхідність звернення особистості до психолога та наслідки, які можуть супроводжувати в разі неготовності вчасно звертатися до спеціаліста за психологічною допомогою. Переважка більшість досліджуваних бачать свій подальший професійний розвиток пов'язаним зі спеціальністю, що може виявлятися в професійній самореалізації в ролі психолога-практика або в подальшому навчанні в магістратурі, психотерапевтичних школах тощо. Такі студенти постійно знаходяться в пошуках себе як професіонала, включаються в різноманітні волонтерські проєкти, займають більш активну позицію під час проходження виробничої практики, намагаючись отримати більше знань, відпрацювати практичні навички психодіагностики та психологічного консультування.

Майже в половини студентів нашого дослідження $(48,18 \%)$ було виявлено середній рівень емоційно-ціннісного ставлення до обраної професії. Такі студенти переважно мають позитивне ціннісне ставлення до професії «психолог», розуміючи ії суспільну важливість, актуальність у сьогоденні, що пов'язані 3 наявністю в Україні військового конфлікту, постійних економічних труднощів, які переживає населення, проблем виховання та сімейних конфліктів. Однак, такі респонденти часто сумніваються у можливості власної реалізації в обраній спеціальності, акцентуючи увагу на проблемах відсутності досвіду надання реальної психологічної допомоги, недостатньому розумінні теоретичних аспектів діяльності психологічної служби, малої кількості вакансій для психологів-початківців, а в разі наявності таких - малій заробітній платі для початківців, зокрема, в школах. Тобто, частіше за все, ставлення до професії загалом позитивне, але через наявні сумніви щодо власної самореалізації в ній відбувається незначне знецінення та надання переваги більш «швидким» сферам реалізації студентів психологічних спеціальностей (відділи роботи 3 персоналом, маркетинг, менеджмент тощо).

Низький рівень емоційно-ціннісного ставлення до професії «психолог» було виявлено в третини досліджуваних (30,00\%). Досліджуваним 3 таким рівнем часто притаманне знецінення професії «психолога», що може проявлятися в нерозумінні суспільної користі для населення, небажанні працювати за обраною спеціальністю та невизначеністю щодо подальшого свого професійного майбутнього.

Якщо порівнювати студентів різних курсів, то можемо відмітити, що на першому курсі найчастіше, в порівнянні зі старшими, діагностується високий рівень ціннісного ставлення до обраної спеціальності та майбутньої професії. Такий рівень виявлений у $34,62 \%$ респондентів, що суттєво перевищує відповідний показник на другому $(13,80 \%)$, третьому $(17,86 \%)$ та четвертому (22,22\%) курсах. Це, в першу чергу, пов'язано з тим, що студенти першого курсу мають певну «зачарованість» професією, не розуміючи всіх складнощів, які треба пройти майбутньому фахівцю протягом навчання та на перших етапах професійного становлення. 3 іншої сторони, на нашу думку, цей показник дозволяє стверджувати, що на сьогоднішній день більшість тих, хто вступає на психологічні спеціальності, мають високий рівень вмотивованості та зацікавленість у подальшому становленні в межах спеціальності, а значить, за правильної організації навчального процесу й розподілу часу зі сторони студентів, можна підтримувати цей рівень мотивації й ціннісного та емоційного ставлення на високому рівні. Також хотілося б відмітити, що на першому курсі було зафіксовано 26,92\% досліджуваних, у 
яких діагностовано низький рівень емоційно-ціннісного ставлення. Враховуючи те, що вибір спеціальності відбувався відносно недавно, а сьогодні більшість абітурієнтів мають можливість вільно обирати й майбутню професію, й 3ВО, де вони будуть навчатися, нам здається цей показник досить високим. У бесідах з такими студентами було з'ясовано, що більшість з них взагалі не бачать мотивації до навчання, спеціальність була нав'язана ззовні від батьків й обрана як «проста та легка» або «єдина цікава з переліку доступних».

Як бачимо з таблиці, в студентів другого курсу вже суттєво переважає середній рівень емоційного ставлення до професії, в той же час показник високого рівня складає всього 13,80\%. Суттєву роль у такому бачені студентів відіграє досить велика кількість теоретичних та непрофільних дисциплін. Студенти пояснюють таке ставлення тим, що отримуючи велику кількість інформації про психологічні теорії особистості та теорії розвитку, вони не можуть це перевірити на практиці. За їхніми словами, їм «хочеться більше практики, перевіряти отриманні знання та свої власні професійні сили». Схожі показники діагностовано на третьому курсі, де середній рівень емоційного ставлення до професії виявлено у 53,57\%, а високий - у 17,86\% досліджуваних. Індивідуальні бесіди дозволили відзначити, що вибір спеціалізації змусив студентів третього курсу трохи зосередитися на певній сфері власної реалізації як психолога а, отже, спробувати співвіднести себе з «конкретним спеціалістом». До того ж, у цей період відсутні загальнонаукові дисципліни, а тому студенти мають можливість зосередитися виключно на обраній професії.

У досліджуваних четвертого курсу суттєво відрізняються показники низького рівня позитивного емоційно-ціннісного ставлення $(40,74 \%)$, водночас, високий рівень складає $22,22 \%$, а середній - 37,04\%. Основна причина такого показника полягає в необхідності визначитися щодо подальшого професійного майбутнього та своєї власної готовності до повноцінної й самостійної діяльності як психолога. Більшість опитаних студентів стверджували, що вони визнають загальну користь навчання на психологічній спеціальності для їхнього життя та, навіть, бачать користь від застосування цих знань у теперішній роботі (непрофільній), однак не бачать у собі тих якостей, знань та вмінь, які могли б їм допомогти успішно реалізуватися як психологам. При цьому, варто зазначити, що більшість студентів дійсно достатньо оволоділи професійними компетенціями, проте усвідомлення професійної відповідальності та відсутність практичного застосування отриманих умінь, не дозволяє їм впевнено позиціонувати себе як психолога.

Цікавим, на нашу думку, $є$ те, що показники активності по відношенню до оволодіння професією не мають суттєвих коливань, таких як емоційно-ціннісне ставлення.

Розглядаючи показники рівнів вияву активної позиції щодо власного професійного розвитку, можемо відзначити, що загалом серед всіх студентів I-IV курсів ці показники не мають таких відмінностей як показники емоційного ставлення до професії. Так, високий рівень активності виявлено в 31,82\% опитаних. Такі досліджувані докладають багато зусиль для оволодіння професійними навичками та розуміння теоретичного матеріалу, приділяють такому вивченню велику кількість позааудиторного часу. Водночас, студенти стверджують, що окрім вивчення навчальних дисциплін в університеті, вони відвідують додаткові навчальні заходи, приймають участь у конференціях, майстер-класах та, в окремих випадках, вже визначились із психотерапевтичним методом, у межах якого почали психотерапевтичну підготовку. Мотивація до такої активної діяльності могла бути різною. Безумовно, переважна більшість досліджуваних із високим рівнем вияву активної позиції щодо оволодіння своєю професією, мотивують себе бажанням у майбутньому бути готовим до професійної діяльності, 
розуміти особливості надання психологічної допомоги, вивчення різноманітних технік такої допомоги, а також загалом високим рівнем пізнавальної активності. Водночас, частина опитаних стверджували, що роблять це автоматично, бо «звикли навчатися», «батьки вимагають успішності» або через необхідність отримувати стипендію.

Таблиия 2

Кількісні показники (\%) рівнів прояву активної позиції до власної майбутньої професії у студентів I-V курсів

\begin{tabular}{|c|c|c|c|c|c|c|}
\multicolumn{1}{|c|}{ Високий } & \multicolumn{2}{c|}{ Середній } & \multicolumn{2}{c|}{ Низький } \\
\hline & $\mathrm{n}$ & $\%$ & $\mathrm{n}$ & $\%$ & $\mathrm{n}$ & $\%$ \\
\hline I курс $(\mathrm{n}=26)$ & 9 & 34,62 & 12 & 46,15 & 5 & 19,23 \\
\hline II курс $(\mathrm{n}=29)$ & 11 & 37,93 & 11 & 37,93 & 7 & 24,14 \\
\hline III курс $(\mathrm{n}=28)$ & 6 & 21,43 & 12 & 42,86 & 10 & 35,71 \\
\hline IV курс $(\mathrm{n}=27)$ & 9 & 33,33 & 8 & 29,63 & 10 & 37,04 \\
\hline Загалом $(\mathrm{n}=110)$ & 35 & 31,82 & 43 & 39,09 & 32 & 29,09 \\
\hline
\end{tabular}

Набільше представленим (39,09\%) був середній рівень вияву активної позиції щодо власного професійного розвитку. Такі досліджувані загалом докладають достатньо зусиль для оволодіння навчальним матеріалом й успішного складання екзаменаційно-залікової сесії. Додаткові заходи вони відвідують у разі дуже сильного зацікавлення темою або «за компанію» 3 одногрупниками. Таких студентів не завжди можна назвати невмотивованими, іноді неможливість приділяти більше часу додатковому навчанню пов'язана 3 необхідністю працювати після навчання або невмінням організовувати свій вільний час.

Низький рівень вияву активної позиції щодо оволодіння власною професію діагностовано в 29,09\% респондентів. Студенти з таким рівнем часто мають труднощі із вивченням навчальних дисциплін й академічною успішністю загалом. Такі досліджувані часто вказували, що ті знання, які їм можуть дати в університеті не актуальні для їхніх подальших життєвих планів, адже вони не планують працювати в межах спеціальності. Можна прослідкувати й взаємозв'язок між рівнем розвитку активної позиції до оволодіння професією та рівнем ціннісно-емоційного ставлення до неї.

Розглядаючи показники розвитку активної позиції щодо оволодіння професією за курсами, варто відзначити, що досить значно представлений показник низького рівня на першому курсі (19,23\%). Так, на нашу думку, це пов'язано з тим, що більшість студентів починає вивчати психологію вперше й, на думку самих опитуваних, починають вчитися 3 самого початку. Однак, різноманітні труднощі (побутові, організаційні та сімейні), особливості адаптації до нових умов навчання призводять до зменшення кількісті часу та зусиль, що студенти здатні приділяти навчанню.

На наше переконання, важливо звернути особливу увагу на особливості адаптації студентів до навчального процесу в університеті. Цей період відрізняється пошуком себе та намаганням спробувати та «приміряти» різні спеціальності. Багато першокурсників змушені змінювати місце та умови проживання, навчальний колектив, виконувати вимоги зі сторони педагогів та навчального процесу. Також варто відзначити адаптацію в середині студентського колективу та звернути увагу на побудову взаємовідносин в середині студентської групи, де останні будуть здатні та готові розкриватися й довіряти один одному. Особливо це стосується підготовки спеціалістів зі спеціальності «Психологія». Адже майбутній психолог це не просто 
носій засвоєних навичок чи компетенцій, це особистість, яка навчилася приймати себе та інших, будувати взаємини на партнерських засадах. Водночас, такі взаємини на основі рівності, взаємоповаги дозволять студентам відчувати підтримку один одного, в складних ситуаціях невдач чи розчарувань «витягувати» одногрупників із кризових станів, ділитися можливостями професійного зростання

\section{Висновки}

Проведений теоретичний аналіз дозволяє побачити актуальність теми становлення професійної ідентичності майбутній психологів (консультантів). Більшість вчених акцентує увагу на значенні стадій (етапів) професійної ідентичності, вказуючи на ключову роль перших етапів професійного ставлення психологів. Саме на цих етапах відбувається відсіювання, навчання та засвоєння базових навичок, прийняття етичних норм, вироблення власного професійного стилю та вимог до розвитку. Цей етап важливий також переходом загальних уявлень про професію, які студенти отримують із популярної літератури, телепередач та книг, до чітких вимог та принципів роботи.

Отже, емпіричне дослідження дозволило дослідити особливості розвитку професійної ідентичності майбутніх психологів протягом навчання на бакалавраті. Було визначено, що емоційне ставлення майбутніх психологів до власної професії розвивається нерівномірно. Так, на старших курсах можна частіше зустріти негативне ставлення до майбутньої професії, що, на нашу думку, часто пов'язано з необхідністю остаточно вибирати подальший професійний шлях та визнавати власний рівень компетентності. Водночас, можна побачити, що навіть студенти із негативним емоційно-ціннісним ставленням до професії часто продовжують систематично навчатися й докладають немало зусиль для успішного завершення навчання.

На нашу думку, негативне ставлення та неприйняття себе в ролі психолога часто пов'язане із низькою адаптацією студентів до навчального процесу, відсутністю позитивного психологічного клімату всередині групи, недостатньою кількість навчальних годин, спрямованих на особистісний розвиток студентів.

Перспективи подальших розвідок ми вбачаємо в детальному емпіричному вивченні причин знецінення студентами професії психолога протягом навчання в університеті та їхньої неготовності залучатися до практичної діяльності після завершення навчання.

\section{Література}

1. Левченко, В.В. (2019). Психологічний супровід формування професійної ідентичності в умовах змін. Теоретичні і прикладні проблеми психологї, 3(50), 196-207.

2. Ляшенко, О.А. (2015). Розвиток професійної ідентичності як чинника становлення психологічної позиції рівності майбутніх викладачів. Науковий часопис НПУ імені М.П. Драгоманова. Серія 12. Психологічні науки, 2(47), 109-115.

3. Родыгина, У.С. (2007). Психологические особенности профессиональной идентичности студентов. Психологическая наука и образование, 12(4), 39-51

4. Auxier, C.R., Hughes, F.R., \& Kline, W.B. (2003). Identity development in counselors-intraining. Counselor Education and Development, 43, 25-38. https://doi.org/10.1002/j.15566978.2003.tb01827.x

5. Rønnestad, M.H., \& Skovholt, T.M. (1993). Supervision of beginning and advanced graduate students of counseling and psychotherapy. Journal of Counseling and Development, 71, 396-405. https://doi.org/10.1002/j.1556-6676.1993.tb02655.x 
6. Rønnestad, M.H., \& Skovholt, T.M. (2013). The developing practitioner: Growth and stagnation of therapists and counselors. Routledge.

7. Thacker, N.E., \& Diambra, J.F. (2019). Parallel Process of Professional Identity Development during Clinical Supervision. Journal of Counselor Preparation and Supervision, 12(3).

\section{References}

1. Levchenko, V.V. (2019). Psykholohichnyi suprovid formuvannia profesiinoi identychnosti v umovakh zmin [Psychological support for the formation of professional identity in the face of change.]. Teoretychni i prykladni problemy psykholohii - Theoretica and applied problems of psychology, 3(50), 196-207 [in Ukrainian].

2. Liashenko, O.A. (2015). Rozvytok profesiinoi identychnosti yak chynnyka stanovlennia psykholohichnoi pozytsii rivnosti maibutnikh vykladachiv [Development of professional identity as a factor in the formation of the psychological position of equality of future teachers.]. Naukovyi chasopys NPU imeni M.P. Drahomanova. Seriia 12. Psykholohichni nauky - Scientific journal of NPU named after MP Драгоманова. Series 12. Psychological sciences, 2(47), 109-115 [in Ukrainian].

3. Rodygina U.S. (2007). Psihologicheskie osobennosti professionalnoj identichnosti studentov [Psychological features of students' professional identity]. Psihologicheskaya nauka $i$ obrazovanie - Psychological science and education,12(4), 39-51 [in Russian]

4. Auxier, C.R., Hughes, F.R., \& Kline, W.B. (2003). Identity development in counselors-intraining. Counselor Education and Development, 43, 25-38. https://doi.org/10.1002/j.15566978.2003.tb01827.x

5. Rønnestad, M.H. \& Skovholt, T.M. (1993). Supervision of beginning and advanced graduate students of counseling and psychotherapy. Journal of Counseling and Development, 71, 396-405. https://doi.org/10.1002/j.1556-6676.1993.tb02655.x

6. Rønnestad, M.H., \& Skovholt, T.M. (2013). The developing practitioner: Growth and stagnation of therapists and counselors. Routledge.

7. Thacker, N.E., \& Diambra, J.F. (2019). Parallel Process of Professional Identity Development during Clinical Supervision. Journal of Counselor Preparation and Supervision, 12(3). 


\title{
PECULIARITIES OF FUTURE PSYCHOLOGISTS' PROFESSIONAL IDENTITY FORMATION DURING STUDY \\ Oleksii Liashenko \\ PhD in Psychology, Associate Professor of \\ the Department of Theoretical and Counselling Psychology \\ National Pedagogical Dragomanov University \\ 9, Pyrohov Str., Kyiv, Ukraine, 01601 \\ o.a.lyashenko@npu.edu.ua https://orcid.org/0000-0002-2942-8284
}

\begin{abstract}
The article outlines the problem of professional identity formation for future psychologists. The empirical study of the differences in the development of professional identity indicators at different stages of future psychologist training in the bachelor's degree is aimed. The main views of scientists on the process of professional development of psychologists (consultants, psychotherapists) are theoretically studied. Features of professional identities of psychologists are considered in comparison with the other professions. The importance of paying attention to the future psychologists' professional identity formation on the stage of their studying in a higher educational institution is emphasized. The key periods of professional identity development of specialists working in the specialty are considered. Particularly a student period is highlighted, within which a clear vision of oneself as a future psychologist should be formed and a vision of their own professional path should be outlined. The peculiarities of the manifestation of professional identity from the first to the fourth year of undergraduate study have been empirically investigated. The peculiarities of students' emotional attitude to their own profession and active position on mastering the profession of a psychologist are considered in detail. The main focus is on changing the emotional attitude to the specialty and profession from positive to negative. Among the main reasons for this depreciation are the maladaptation of students at the beginning of training, the tense psychological climate in the student group, the small number of study hours devoted to the personal development of students, and the development of willingness to interact with clients. As a result, senior students are psychologically unprepared for professional activities, and therefore choose other ways of self-realization. The conclusions suggest that negative attitudes and rejection of a psychologist's role are often associated with low adaptation of students to the learning process, lack of positive psychological climate within the group, insufficient number of teaching hours aimed at personal development of students.
\end{abstract}

Keywords: professional identity, professional formation of a psychologist, counselor, active position, attitude towards the profession as a value, study adaptation. 